\title{
Lessons for Citizens Regarding Government Efforts to Promote Covid-19 Vaccines: Responses and Challenges to Post-Pandemic Citizenship Education
}

\author{
Chris Apandie ${ }^{1, *}$, Silvia Rahmelia ${ }^{2}$ \\ ${ }^{1,2}$ Institut Agama Kristen Negeri Palangka Raya \\ *Corresponding author. Email:capandie@gmail.com
}

\begin{abstract}
Presence of Covid-19 vaccine does not actually imply public consent and obedience to the government's rule for vaccine injections. There are still citizens who do not follow this vaccination rule, especially in Indonesia there are many concerns about effectiveness of it's vaccine. Disobedience of citizens with vaccines becoming a phenomenon, especially about mutual relations and synergy between government and citizens. This issue is part of Citizenship Education that aims to strengthen democratic education by educating citizens about government compliance. As for this research aims to develop perspective on the new lessons of citizens to civic culture as a result during this pandemic. Moreover, it is an answer and also challenge to post pandemic citizenship education, related to citizens' participation in effectiveness government policy. This research uses a qualitative approach with literature study method. Main concepts in this research become instruments for conducting data on processing data procedures. Data processing with literature method done by identifying various references related to the main topic. Several findings and main themes were obtained, as follows: 1) Lessons to post-pandemic Citizenship Education is to build an optimistic attitude of citizens to government; 2) Education through information disclosure by government in the main communication media to enhance public digital literacy; 3) Strengthening educational democracy with citizen participation in order to policies implementation; 4) Support for dialogue practices between segments of society to enrich perspective of Citizenship Education. Therefore, implication of this research is that Citizenship Education needs to adjust it's subject matter after the pandemic (Post-Pandemic Citizenship Education) through strengthening awareness and it's understanding about urgency of citizen participation to realize effectiveness government policies.
\end{abstract}

Keywords: Citizenship Education, Covid-19, Vaccines.

\section{INTRODUCTION}

The coronavirus Covid-19 pandemic has brought a new era in citizens' lives. The era that we call a new normal has become a new part of social interaction and also an impact on cultural shift of citizens. One year on, Covid-19 pandemic had a significant impact in almost all life aspects. Both economics, politics, education and even tourism. "COVID-19 has generated massive socioeconomic impacts globally"[1]. Increasing number of data survivor in Indonesia makes public panic, in terms of handling of the government which is still groping. Many health workers have died and economy aspect has become paralyzed. Institutional synergy and coordination also had a crisis. It's situation is almost same in America, where the President and the Governor of the State are arguing over a number of issues and policies on COVID19. Apart from internal government, synergy also includes of involvement on non-state actors and citizens. Absence of synergy and coordination will lead to fragmented handling, which will only exacerbate the situation. "The failure of synergy and coordination between elements in responding to pandemic threat will be paid by a deep humanitarian crisis"[2].

However, the presence of Covid-19 vaccine in early 2021 has brought a bright spot in dealing with Covid-19. Health protocols that continue to implemented so strictly supported by government policies based on expert research have made the public such a little optimistic that this pandemic will be passed. In fact, the presence of Covid-19 vaccine produced by various countries in the world does not immediately make people agree to obey the government's call for vaccine injections. Citizens' disobidience with government policies can be caused by the efficacy of vaccines circulating (Sinovac) in Indonesia is only around $65 \%[3]$. This indicates that there has been no significant response from the community in forming synergies in dealing with the 
pandemic. The research of Fajar Fathur Rachman and Setia Permana in 2020 revealed an analysis sentiment of the pros and cons of Indonesian people regarding Covid19 vaccine on Twitter. Public has concerns that this vaccine seems rushed and not well planned. In addition to the feared side effects of Covid-19 vaccine, one of the most frequently spoken words of public regarding the planned vaccination activities to carried out by the government is halal (allowed in Islam) status of the vaccine "[4]

Even though it has been well designed based on age and also consider side effects of vaccine, there are still many people who are reluctant and afraid to use vaccine. This incident certainly made the deadline that set by government inappropriate. "Vaccines are aimed at every Indonesian citizen, both abroad and domestically, because every Indonesian citizen has the same rights, especially in the protection of deadly diseases"[5]. Many factors trigger public doubts about Covid-19 vaccination. Even the fatwa (the rules of Indonesian religious leaders council called Majelis Ulama Indonesia) doesn't seem effective in convincing public.

Other than that, hoax news go along circulating on social media about the dangers of Covid-19 vaccine, it was accompanied by increasing data survivor after injecting it's vaccine. This made the public distrust about vaccination strategy which implemented by the Government. Seeing this, citizens need to be convinced by role models and religious figures or community leaders and even influencers to socialize about the importance of vaccines as the most effective pandemic management strategy.

Especially for religious leaders, it is necessary to spread moderate religious mindset. Because several surveys stated that the rejection of this vaccine was also based on a religious view of fatalism. While moderate religious mindset teaches questions to experts, including about Covid-19 vaccination, if it is about halal haram (allowed or not allowed in Islam), MUI has guaranteed it through epidemiologists who are strengthened by the legality of BPOM (National Agency of Drug and Food Control in Indonesia). "BPOM has issued Emergency Use Authorization (EUA), which is a permit for emergency use of Sinovac Covid-19 Vaccine. Likewise, MUI has issued a fatwa that vaccines are allowed and clean "[6]. The characteristics of Indonesian society which tend to will not to accept changes has create its own difficulties. Although scientific research has been released coupled with the strengthening of religious norms to legal norms, synergy of citizens has not seen at the beginning of vaccination program. Handling the COVID-19 pandemic apart from requiring strong political will from the Government, also requires adequate policies that are able to guarantee transparent governance and fulfill the citizens' rights health in terms of crisis situations like this[7]. However, the vaccination program is gradually being well socialized to citizens, supported by the role of smart citizens in digesting information conveyed by local governments.
Appealing this incident on the axis of state and citizen's life, between the state and citizens there is a reciprocal relationship that needs to be strengthened by synergy in order to achieve target of handling Covid-19 pandemic effectively. Citizens need to succeed Covid-19 Vaccination program which has been scheduled by the government. However, the reality is many parties create chaos amidst the government's focus in disseminating this vaccine. Nonetheless, the National Survey of Research and Development Center for the Ministry of Religion in Indonesia regarding "Religious responses about Covid-19

Vaccination Plan" stated that $9.39 \%$ refused vaccination, $36.25 \%$ had not decided yet, and the majority of the citizens in the amount of $54.337 \%$ are ready to vaccinated"[6]. These findings indicate that there are pros and cons in citizens regarding Covid-19 vaccination. Many people who refuse vaccination because of the safety of it's vaccine, in the amount of $9.27 \%$ because of religious issues. While respondents who decided yet, wait and see are still looking for vaccines details and vaccination plans.

Citizenship education as part of democratic pillars in Indonesia needs to take a part in responding to the challenges ahead. This is because citizenship issues are related to human right, public facilities and problems related to citizens' life [8]. Learning from the government's handling of Covid-19 Pandemic, many things have become new lessons for citizens. This study aims to provide a starting point in exploring it's new lessons by learning from government's handling of Covid-19 pandemic, especially regarding Covid-19 vaccination. The emergence of this idea is expected to strengthen the scientific of Citizenship Education, so it can be more persistent in exploring contextual Citizenship Education. There are several things that should be strengthened in efforts to develop Civics concept in response to Covid-19 Pandemic, there are 1) Lesson in terms of building an optimistic attitude towards citizens; 2) Lesson through public information disclosure in the mainstream media; 3) Strengthening democratic education with citizen participation in policy implementation; 4) Support for the practice of dialogue between segments of society to enrich the perspective of citizenship education.

\section{THEORETICAL REVIEW}

\subsection{Covid-19}

Since March 2020, Covid-19 was first confirmed in Indonesia, followed by a growing number of cases reaching a mortality rate of $8.9 \%$. The SARS-CoV-2 virus spreads from human to human[9]. Many of initial allegations related to Covid-19 were part of a conspiracy. There are also those who reveal that this virus originated from a laboratory leak in China. However, these allegations have been declared scientifically incorrect. To this day, researchers from WHO are still being sent to Wuhan, China as the initial location for the spread of the virus to trace scientific evidence of how this virus spreads. 
The first case of Covid-19 was found in Wuhan, China in early February 2020. This virus spreads rapidly to various countries due to uncontrolled mobility of citizens. Moreover, this virus spreads from human to human through droplets that come out when coughing and sneezing. COVID-19 has a wider impact because of the characteristics of disease that is transmitted directly between humans. "The characteristics of the virus and such transmission patterns make COVID-19 more difficult to manage, especially given a very high crossborder mobility of humans"[10]. Unexpectedly, this invisible virus has changed the behavior of citizens until a new normal era as a new culture come. Wear a mask, keep your distance, avoid crowds, wash your hands and minimize mobility. These restrictions make citizens' lives change drastically. Nevertheless, human instincts are able to well adapt in a new environments and situations, so that some activities can be carried out again by implementing health protocols and several provisions which are also regulated in local government policies.

\subsection{Covid-19 Vaccination Program and Indonesia's Government Efforts}

Covid-19 virus have implemented policies to prevent it's spread through social restrictions and regional quarantine. This policy is accompanied by sanctions for social distancing offender. Tracing is also carried out by utilizing technology in policies to prevent the spread of this virus. However, policies related to special budgets allocated to improving health services and developing vaccines have recently been implemented by countries such as America, South Korea, Singapore and Taiwan. An interesting thing besides the economic stimulus policy in accompanying Covid-19 vaccination program by the government is involvement of citizens through fundraising such as the courage fund carried out by Singapore[11]. Handling Covid-19 requires a strong and in-depth study from the Government, with the utilize of valid data and a well-managed budget, so the state can basically handle a pandemic in its country.

Countries that are quite responsive in handling Covid-19 pandemic include several indicators such as ability to plan and coordinating institutions within the framework of national emergency preparedness, ability to provide an accurate information and data such as data survivor and managed tracking mechanisms. Coupled with ownership of a country on clear policies related to prevention of disease's spread and budget allocations disbursed to improve health services, ensure the availability of medical facilities and equipment as well as protection for medical personnel[11]

Another effort made by the government is through research to produce vaccines. "Fulfillment of Covid-19 vaccine is government's responsibility as it is a form of realizing the country's goals"[12]. Vaccines are considered to be the most effective in tackling the spread of Covid-19 virus. The purpose of the vaccine is to provide immunity against disease, so that if there is no benefit from the vaccine, there will be no immunity against the body of vaccine user and more susceptible to disease[13], [14].

Regulations for Covid-19 vaccine are contained in Presidential Regulation Number 99 of 2020 concerning Vaccines Procurement and Implementation of Vaccinations in the Context of Corona Virus Disease 2019 (Covid-19) Pandemic and Regulation of Minister of Health Number 84 of 2020 concerning Implementation of Vaccinations in the Context of tCovid- 19 pandemic. Presidential Regulation on vaccines mostly regulates cooperation in vaccine distribution and also has several roles in implementing vaccine distribution in Indonesia.

Implementation of policies in addition to efforts and equalize Covid-19 vaccination, Indonesian government through the National Development Planning Agency[15] recommends 1) require social distancing; 2) expanded rapid test for screening and extended PCR lab tests with gen expert; 3) enforcing special policies for Ramadan, Eid and Easter; 4) meet the needs of health services.

\subsection{Citizenship Education during Pandemic and Post-Pandemic}

According to Law Number 20 of 2003 Article 37, Citizenship Education functions as general education in addition to Religious Education and Pancasila education for all types and levels of education. In Article 37, explained that "Citizenship Education is an effort to equip students with basic knowledge and abilities relating to relationship between citizens and the state as well as preliminary education to defend the state in order to become a citizen who can be relied on by the nation and state. At higher education level, state defense education is held through Civic Education". Civic Education basically help to configurate citizens with an efficient and independent mindset.

During Covid-19 pandemic, citizens has an important role in helping the government. Even in the concept of citizenship, implementing health protocols is included in attitude and behavior of defending state during this pandemic. Basically, the relationship between citizens and the state is quite extensive and will involve citizens and state reciprocally with almost all basic human activities in the fields and activities of politics, economy, law, transportation, communications, security, health, until to expressing values of arts and religion [16]. So it's not surprising that every change occurs in society must be related to additions in concept and practice of Civics Education or Civics.

Post-pandemic Citizenship Education needs to emphasize lessons of citizens regarding public participation which is very important in terms running of a policy. Citizens should become subjects who are involved in planning, implementing and supervising a policy. This model is a citizen empowerment model that starts from citizen initiatives as the core of development resources.

Empowerment according to Shardlow concerns the problem of how individuals, groups or communities try to control their own lives and seek to shape the future 
according to their wishes[17]. One of the goals of empowerment is to determine the actions related to themselves, including reducing the effects of personal and social barriers in deciding an action. Citizen empowerment becomes a lesson after this pandemic began to move in new normal era. Citizens need to learn about self-empowerment as part of society. There are at least two interrelated trends in community or citizen empowerment. In this tendency, citizen empowerment emphasized in the process of giving or transferring some power, strength and ability to community or individuals to become more empowered. This process can be complemented by efforts to build material assets to support self-reliance development through the organization. Second, secondary trends. This tendency emphasizes the process of providing stimulants, encouragement or motivation so that individuals or communities have the ability to determine their needs through a dialogue process[18]. Empowerment is expected to foster independence, participation, networks and even justice.

\section{METHOD}

The study conducted to results of thoughts that constructed from various sources. Authors also conducted several discussions with colleagues related to Citizenship Education and Administration/Government Science. Authors choose the systematic literature review method. Systematic literature review is research by examining something on a certain subject. This method also focuses on developing, collecting and evaluating research results related to the specific topic discussed. This research was conducted for various purposes, including to identify, study, evaluate, and interpret all available research with the topic area of phenomenon with certain relevant research questions[19]. Sub-theme of the discussion that was an analysis of government programs to make Covid-19 vaccination a success regarding tolerance, diversity, religious moderation, and Civic Education. As stated by Wahono, stages in the literature review consist of at least 1) Identify the relevant literature; 2) Perform selection of primary studies; 3) Perform data extraction; 4) Assess studies' quality; 5) Conduct synthesis of evidence[20].

So this research is based on literature constructed from facts related to Covid-19 Pandemic, Indonesian government's handling of the Pandemic to the culture of new citizens who emerged in adaptation process during the Covid-19 Pandemic. The ideas involved sources in form of journal articles, electronic media platforms and hearings related to the Covid-19 Pandemic. Eventually, this research can contribute to strengthening Citizenship Education concepts, especially as an initial idea in formation concepts related to new citizen culture and content of Citizenship Education curriculum that is more contextual and flexible.

\section{RESULT AND DISCUSSION}

\subsection{Lesson in terms of Building an Optimistic Mentality towards Citizens}

Citizens during pandemic are experiencing a downturn. From the bottom layer to the top layer has same difficulty. Many people have died from this virus, even with a very rapid spread[9], [10]. For example, education and economic sectors bring citizens into an "out of the box" mindset. Efficacy with technology has become a necessity in the midst of Covid-19 pandemic. Citizens who are initially unfamiliar with technology inevitably have to learn, so that they can continue to adapt the situations during pandemic. Citizens are indirectly educated to adapt new styles in their role as citizens.

This change causes the mindset of citizens also change. There are many things that can not be accepted suddenly, such as the implementation of health protocols that cause interaction between citizens limited[15]. Besides that, a lot of stigma has emerged against the government in the midst of handling Covid-19 pandemic which is still groping. This extraordinary incident provides lessons for various countries including Indonesia in building a more resilient health system. One things that important in this case is the need for mutual trust between citizens and government. In short, additional sources of financial funds are needed to support the health system so that health services can increase directly proportional to the quality of health produced for citizens. The strategy for implementing a more resilient health system can be an example of the attitude of fostering trust and optimism among citizens towards the government. It is difficult to cultivate an optimistic mentality when the existing environment is not supportive. Optimism basically comes from strong intrinsic motivation, of course supported by extrinsic motivation, such as supportive environment, so this optimistic attitude can be achieved. Of course, the government needs to offer good and in-depth designs and strategies so that citizens can be optimistic about the changes that offered.

The covid-19 pandemic has left citizens' lessons. Citizens' trust to government regarding handling this pandemic is still groping amid the increasing distribution of cases as if tested. The number of work dismissals and social assistance that hasn't been distributed evenly, addition cases of corruption in social grants naturally make citizens pessimistic. However, Indonesia government of handling Covid-19 makes citizens learn about compliance with government policies which is unpleasant. Offering a more resilient health system seems very new to citizens in the new normal era. Trust is needed that builds an optimistic mentality towards the government. For example, " trust by survivor, health workers and public to the government is very necessary to be able overcome health crisis"[21]. Citizenship Education needs to respond the challenge of instilling a sense of trust in government performance. If a sense of trust has been built, there will be an optimistic mentality about the results achieved. Because what has happened 
so far, many citizen who actually weaken government's performance. For example, there are still people who do not want to be vaccinated with the reasons that the legality of Covid-19 vaccine imported from liberal countries.

In the theory of disobedience to the law put forward by Thoreu, attitude of rejecting the law (Civil Disobedience) owned by people who decide not to submit to a regulation issued by the ruling government or in short against a public policy. This attitude of rejection usually based on logical reasons about disapproval of society towards a policy[22]. A policy is not always successful, but the government also needs support from citizen on the society so that the policies implemented can be successful. Including the handling of Covid-19. If the citizen can be optimistic, it will be easy to invite people to participate in a policy implementation.

The new lesson from this is Civic Education with a rationality model that results in active citizen participation. Citizenship education with the rationality model same in classical Greek definition. Citizenship education is known to be explicitly political, normative and visionary. "Citizenship education is seen as intrinsically political, designed to educate citizens to participate intelligently and actively in civil society"[23]

However, there is an optimistic mentality off citizens regarding the handling Covid-19 pandemic, especially regarding the vaccination program. The positive response of citizen is dominated by statements that support and believe in discourse on vaccination issued by the government, such as believing that vaccination activities are important to break the chain of virus' spreads. In addition, the public also dominantly believes that the vaccine is safe to use, they are proud of the government's performance and are also optimist that the vaccine will be affordable by all people[4]. This phenomenon indirectly makes it easier for the government to improve coverage of vaccination program, so that the handling of Covid-19 can be controlled. Citizens are expected to accept the programs offered by the government, both related to vaccinations and health systems that are more resilient to be implemented in the post-pandemic period.

\subsection{Lesson through Public Information Disclosure in the Mainstream Media}

Indonesian government has made ineffective public statements regarding controlling spread of Covid-19 from the start of its entry. According to Chairil, in January-February 2020, the government had desecuritization, that's an effort to bring the Covid-19 issue out of the security discourse, so that the issue was not considered a threat that didn't need a security handler. Even though at that time, several parties had warned of Corona Virus spread's possibility in Indonesia[24]

Mechanism and communication run by Indonesian government is somewhat unresponsive. The government has faced criticism over the spread, which only confirmed two cases at that time. Government's handling of Covid-19, including the vaccination program, requires good public communication from the government. So that citizens respond well to information and are able to make appropriate decisions when there are confirmed cases. Indonesian government was not open about Covid-19 data cases. This incident led to more and more misinformation and hoaxes. This information was also reported by CNN Indonesia as follows "the government's openness on distribution data has contributed to panic and confusion of information. This has implications for the emergence of a lot of hoax information. From 23 January to 6 April 2020, the Ministry of Communication and Information (Kemenkominfo in Indonesia) has identified 1,096 hoax issues of COVID-19 that are spread through digital platforms"[24].

To build public trust, government needs to present balanced and accurate information. The government needs to be transparent regarding Covid-19 control data including data on the vaccination program. This is done so that information is not misused and reaches the right target for citizens. Public information disclosure is needed to disseminate information related to government control management. So that government decisionmaking runs in a directed manner, "coordination in the internal sphere is carried out proactively, as well as the delivery of public information that takes place effectively through various communication channels"[25]. This is related to the vaccination program, that the government can use communication channels to disseminate information to citizens regarding the importance of vaccines, the side effects they cause, and vaccine production procedures.

The openness of the government about vaccines and the ingredients in them will be able to ward off negative sentiments in society, such as about vaccines legality. Jimly Asshidiqie stated that in the concept of a democratic rule of law, public information disclosure is the foundation for building good governance, which is transparent, open and participates in all state processes, including the entire process of managing public resources from the process of decision making, implementation and evaluation[26]. Through information disclosure, that is expected it can create a clean political activities, courteous and prioritize the interests public and society "because all aspects that form the basis for government in issuing policies can be known and the reports are transparent to the public"[27]

New lesson for citizens regarding the Covid-19 pandemic and the government's efforts in carrying out the vaccination program is that citizens must increase digital literacy by accessing credible information that has been channeled by the government, suppose through social media and electronic mass media. There needs to be a synergistic effort between government and society. If the government has tried to be transparent in conveying information and striving for credible and accountable data to be presented, then citizens need to learn how to increase digital literacy so that they are not consumed by irresponsible hoax news. Transparency as 
stated by Folscher can increase citizens' trust in government.

Folscher[28] suggested about the advantages of transparency are:

a. Early identification of policy strengths and weaknesses so that the necessary changes can be made quickly;

b. Increase the accountability of the government, legislative, media and can exercise control functions to the government better if they have information about a matter and can prevent corruption;

c. Transparency can increase trust in the government and build closer social relations, for example the public can understand government policies and even support these policies;

\subsection{Strengthening Democratic Education with Citizen Participation}

Democracy education has become a part of Citizenship Education concept. However, many implementations haven't been optimal in this application of democratic education, either at school, university level or its realization in society. It is important to carry out democracy education to increase the literacy of citizen towards the development of life nation and state. In this scope, political literacy is needed towards contextual developments related to citizens role. "Political literacy is a knowledge and understanding of state's political process and political issues, a knowledge and understanding that enables every citizen to effectively carry out his role as a citizen"[29]. The current vaccination program run by Indonesian government brings new lessons for citizens that need to strengthen democratic education to increase citizen participation in supporting government policies.

Citizenship education needs to teach citizens to be responsive to change. There are three zones "who am I in the Covid-19 era" as translated by Annastasia Ediati[30], as follows the fear zone, the learning zone and the growth zone. Citizens should be in the growth zone or at least the learning zone. This growth zone can be proven by good adaptation skills, not falling into difficult situations in the midst of a pandemic. The growth zone is also marked by the emergence of an attitude of confidence and trust in the policies implemented by the government.

Besides that, community empowerment is also part of democratic education that attracts citizens to participate. Learning from the crisis during this pandemic, citizens need to strengthen democratic education by means of empowerment. The empowerment referred to as part of learning in Post-pandemic Citizenship Education emphasizes people-centered development where all levels of society participate in moving to achieve common goals. Through empowerment, at least the active participation of citizens has been achieved. Although basically ideal participation is difficult to find at the practical level, participation can start at the bottom level and progress to the top level into wider fields of decision-making.

Community empowerment doesn't only lead to achieving decision making for an action. This empowerment functions for the implementation of selfactualization, because self-actualization is not only a basic human need but also a collective achievement as in state life. Several options for this citizen empowerment curriculum, as follows: first, empowering the society by "socializing" society roles as a subject, either as the main actor and/or taking part/helping or as a target/user (object) appropriately, correctly and understood as well as increasing the capacity of the community in managing and implementing development activities in all areas of the Ideology, Politics, Economy, Social, Culture, Defense and Security (Ipoleksosbudhankam in Indonesia). Second; Utilizing the "mechanism" for the implementation of development/community empowerment in a more aspirational/democratic, effective, and efficient manner, in accordance with the constitutional/governance and social standards[31].

Covid-19 vaccination not only teaches citizens about synergy and support for the government, but also guides citizens into legal education to carry out legal compliance. Indonesian government's steps are bold enough to impose sanctions for refusing Covid-19 vaccine. In Presidential Regulation Number 14 of 2021, it is stated that there are administrative sanctions to criminal sanctions for everyone who has been designated as Covid-19 vaccine recipients who refuse it. These sanctions will create responsibility on citizens. Therefore it is in line with legal education that should exist in democratic education. As it is said that "responsibility without rules will not possibly be able to go according to what is expected. Likewise, regulations without a sense of responsibility are impossible to implement, so there needs to be an element of coercion"[32]. Citizens sometimes have to be forced to obey and must be forced to learn. Gradually it will be mapped between empowerment programs that have actually been running unconsciously. Strengthened by good legal education and political literacy, the participation of citizens can increase and be proportional to their contribution to the running of a policy.

Legal or law education needs to be strengthened for post-pandemic Civic Education. This offer to develop legal education remains relevant to Citizenship Education goals, which includes discussions such as laws and regulations. Changes towards democratization and maturity as a sovereign nation must be addressed through the development of a new concept of Civic Education as legal/law education[16]. As a consequence of Civics in political, legal, and moral/character education, the ability to participate responsibly for citizens must be in line with legal regulations and moral norms that apply in their society. 


\subsection{Support the Practice of Dialogue Between More Society Segment to Enrich the Perspective of Citizenship Education}

Once citizens are equipped with good legal/law education and political literacy, it is expected that an optimistic attitude towards the government will increase and improve, so that policy implementation can be as expected. The government's public communication in conveying information related to the handling of the Covid-19 pandemic and the vaccination program is a sign that citizen support is getting better. This synergy needs to be maintained in terms of stability by strengthening the practice of dialogue between segments of society that bridges between the scope of research and science producers and the community itself.

The vaccination program cannot run well without support from the community and trust in the government. The government needs to maintain the intensity and intimacy of this synergy by promoting more frequent dialogue among the community. Whether it is related to government programs in particular or to open up the aspirations and evaluations of citizen as the highest power holders (sovereignty by people) in a democratic country like Indonesia.

Learning from Covid-19 vaccination program, it turns out that there are segments of the society who are anti-vaccines motivated by minimal knowledge and lack of trust in government. This contra group has also manifested and penetrated into a wider circle of society life, its groups with anti-government extremist views. This needs to be touched upon in relation to promoting dialogue between segments of society. Whether it is done formally on an academic pulpit or informally.

A survey by Indonesia Ministry of Health in September 2020 stated that $7.6 \%$ of the population refused and $27 \%$ were doubtful about vaccination. As many as $8 \%$ of the people rejected it because of the dimensions of religious belief (religion). A survey by the Ministry of Health identified "religious beliefs" as one of the reasons for refusing vaccines[6]. In this regard, we need to get closer to theological studies as a feature of religious Indonesian society. Regarding the Covid-19 vaccination, which had been rejected, Islamic perception recognizes the Jabariyah sect (humans have no part in what they do) and the Qodariyah sect (humans have free will to determine their own actions). The two extreme currents are now gone. The majority of Muslims in Indonesia who are Sunni Muslims tend to combine that. However, it is undeniable that the jabariyah and qodariyah are still adhered to by the Indonesian people. This is proved from the existence of a view that completely surrenders to God. "He does not believe in human endeavor, everything has been arranged, including health issues"[6]. For such a society, the matter of life and death is God's business, so it can be said that the application of this health protocol does not apply to this society segment. So that rejection of vaccines also occurs because of the great feeling of surrendering to God. Even in the face of corona virus, they have such a fatalistic view. One of them, mid-March 2020, Jama'ah
Tabligh held Ijtima 'Asia Zone World in Gowa, South Sulawesi which was attended by 8,695 people from 48 countries[33]

Meanwhile, perception of the church in Indonesia as a Christian segment related to Covid-19 pandemic and also the Covid-19 vaccination, which is linked by some segment to the 666 and anti-Christian microchip engineering during the Covid-19 pandemic crisis. Rresulting in confusion and fear within God's congregation[34]. This kind of understanding will also hamper the research in the health sector, such as in handling this pandemic. In relation to citizen participation by handling of Covid-19 pandemic, through involvement of society would be a necessary to strengthen it. Especially by encouraging pentahelix partnership patterns among the stakeholders involved, starting from the government (central and local), private elements and business aspect, academic elements, and society[35]. Pentahelix synergy is indeed familiar. This synergy needs to be strengthened by promoting dialogue between segments of society. In the Citizenship Education curriculum, students can be invited to dialect more between religions, cultural groups and certain groups who has the spot or viral.

Furthermore, it is necessary to put forward the integrated dialogue of religion and scientists. Dialogue in question needs to bridge the realms of religion and science in order to be balanced and complementary. Based on the idea according to Harari, human dependence on religion is considered because they have not been able to conquer nature. Now humans are considered as 'gods' themselves because they have the power of science and technology[36]. Dialogue between segments of society should talk about "theology of nature" which integrates the role of man as a subject along with an understanding of God and the universe. There are a number of scientist who are concerned about the relationship between science and religion, such as Keith Ward and Arthur Peacocke who stated that process philosophy can integrate science and religion[37]. Citizens must not against the development of science and technology that seems to cross religious boundaries. Basically, the relationship between citizens and the state is quite extensive and will involve citizens and the state reciprocally, with all basic human activities in the fields and activities of politics, economy, law, transportation communications, security and order, health, to expressing values, arts and religion[16]. Even within Pancasila, there is concept about how Pancasila as basis for the development of science. So there is a boundary line that can hold us together in learning as a citizen who holds the Pancasila as Indonesia's ideology.

\section{CONCLUSION}

Based on the literature research procedures, some of the main findings and themes were obtained, as follows

1. Lesson that enriched civic optimism. Civic Education needs to deal with the challenge for instilling public trust about government performance. If that trust has 
been awakened, there will be an optimistic attitude about the results obtained .

2. Lesson through information disclosure in mainstream media. Education for citizens related to Covid-19 pandemic and vaccination program is that citizens should improve digital literacy by accessing reliable information that has been channeled by the government through social media and electronic media.

3. Strengthening democratic education with citizens participation for effectiveness policies implementation. Post-pandemic Citizenship education should addressed by developing new concepts based on law education to align synergy and citizen's support for government.

4. Support the practices of dialogue between segments of society to enrich Civic Education's perspective. In this case, it is necessary to present an integrated religious and scientific dialogue to create a bridge between both of domains. Post-pandemic Civic Education perspective needs to further developed by instilling dialogue practice between segments of society in both formal and practical community curriculum.

\section{REFERENCES}

[1] W. Masudi and P. Winanti, "COVID-19: Dari Krisis Kesehatan ke Krisis Tata Kelola," in Tata Kelola Penanganan Covid-19: Kajian Awal, Yogyakarta: Gadjah Mada University Press, 2020.

[2] A. McConnell, "Success? Failure? Something inbetween? A framework for evaluating crisis management," Policy Soc. J., vol. 3, no. 2, 2011.

[3] Y. A. Rahman, "Vaksinasi Massal Covid-19 sebagai Sebuah Upaya Masyarakat dalam Melaksanakan Kepatuhan Hukum (Obedience Law)," Khazanah Huk., vol. 3, no. 2, pp. 80-86, 2021.

[4] F. F. Rachman and S. Pramana, "Analisis Sentimen Pro dan Kontra Masyarakat Indonesia tentang Vaksin COVID-19 pada Media Sosial Twitter," Heal. Inf. Manag. J. ISSN, vol. 8, no. 2, pp. 2655-9129, 2020.

[5] I. K. L. Perbawa, "KEBIJAKAN PEMERINTAH INDONESIA DALAM MENANGGULANGI COVID-19 BERDASARKAN," J. Ilmu Sos. dan Hum., vol. 10, no. 1, pp. 197-205, 2021.

[6] A. Sofanudin, "Dimensi Teologis dalam Vaksin," 2021.

[7] A. Widaningrum and W. Masudi, "Dinamika Respons Pemerintah Nasional: Krisis Kebijakan Penanganan COVID-19," in Tata Kelola Penanganan Covid-19: Kajian Awal, Yogyakarta: Gadjah Mada University Press, 2020.

[8] M. F. Hastangka, "Kebijakan Politik Presiden Jokowi Terhadap Masalah Kewarganegaraan
Dalam Merespons Isu Global: Studi Kasus Covid-19," Citizsh. J. Pancasila dan Kewarganegaraan, vol. 8, no. 1, pp. 1-13, 2020.

[9] W. Orensteina and R. Ahmed, "Simply put:Vaccinationsaves lives," Proc Natl Acad Sci USA, vol. 114, no. 16, 2017.

[10] M. A. Shereen, "COVID-19 infection: Origin, transmission, and characteristics of human coronaviruses," J. Adv. Res., vol. 24, pp. 91-98, 2020.

[11] P. Winanti, P. Darmawan, and P. Treviliana, "Komparasi Kebijakan Negara: Menakar Kesiapan dan Kesigapan Menangani," in Tata Kelola Penanganan Covid-19: Kajian Awal, Yogyakarta: Gadjah Mada University Press, 2020.

[12] A. Masnun, E. Sulistyowati, and I. Ronaboyd, "PELINDUNGAN HUKUM ATAS VAKSIN COVID-19 DAN TANGGUNG JAWAB NEGARA PEMENUHAN VAKSIN DALAM MEWUJUDKAN NEGARA KESEJAHTERAAN,” DiH J. Ilmu Huk., vol. 17, no. 1, 2021.

[13] R. Olivia, S Gibson, O Nasrudin, "Indonesia in the Time of Covid-19," Bull. Indones. Econ. Stud., vol. 56, no. 2, pp. 143-174, 2020.

[14] R. Yunus and A. Rezki, "Kebijakan Pemberlakuan Lockdown Sebagai Antisipasi Penyebaran Corona Virus Covid-19," J. Sos. Budaya Syar-I FSH UIN Syarif Hidayatullah Jakarta, vol. 7, no. 3, pp. 227-238, 2020.

[15] I. Ariawan, P. Riono, M. Farid, and H. Jusril, "COVID-19 Modelling Scenarios Indonesia," 2020.

[16] S. L, "Pendidikan Kewarganegaraan Sebagai Pendidikan Nilai Dan Pendidikan Hukum Dalam Mewujudkan Warga Negara Yang Cerdas Dan Baik (Smart and Good Citizen)," J. Pemikir. dan Penelit. Ilmu-ilmu Sos. Hukum, Pengajarannya, vol. XIV, no. 2, pp. 115-116, 2019.

[17] R. A. Isbandi, Pemikiran-pemikiran dalam Pembangunan Kesejahteraan Sosial. Jakarta: Lembaga Penerbit Fakultas Ekonomi Universitas Indonesia, 2002.

[18] K. Adimiharja, Participatory Research Appraisal dalam Pelaksanaan Pengabdian kepada Masyarakat. Bandung: Humaniora, 2001.

[19] Lusiana dan M. Suryani, "Metode SLR untuk Mengidentifikasi Isu-Isu dalam Software Engineering," Sains dan Teknol. Inf., vol. 3, no. 1, 2014.

[20] Romi Satria Wahono, “A Systematic Literature Review of Software Defect Prediction: Research Trends, Datasets, Methods and Frameworks," J. Softw. Eng., vol. 1, no. 1, pp. 1-16, 2015.

[21] Q. Legido, N. Asgari, Y. Teo, G. Leung, H. Oshitani, and Fukuda, "Are high-performing health systems resilient against the COVID-19 epidemic?," Lancet, vol. 395, no. 10227, pp. 848-850, 2020. 
[22] H. D. Thoreau and A. MacLeish, Civil disobedience. Virginia: Virginia Tech, 2001.

[23] H. A. Giroux, "Critical Theory and Rationaloty in Citizenship Education," Curric. Inq., vol. 10, no. $4,1980$.

[24] CNN Indonesia, "Jokowi di antara visi pembangunan dan kemanusiaan," 17 Maret 2020, 2020. .

[25] M. Yu, Z. Li, and J. Zhou, "Communication related health crisis on social media: A case of COVID-19 outbreak," Current Issues in Tourism, 2020. .

[26] J. Asshidiqie, Format Kelembagaan Negara dan Pergeseran kekuasaan dalam UUD 1945. Jakarta: Fakultas Hukum Universitas Indonesia Press, 2003.

[27] E. Nurdiansyah, "Mewujudkan Transparansi Bagi Masyarakat," J. Bhinneka Tunggal Ika, vol. 3, no. 2, pp. 147-151, 2016.

[28] Folscher, "Transparency and Participation in The Budget Process," South Africa, 2000.

[29] B. Yuniarto, "MEMBANGUN N SI MELALUI EKATAN UAL BELAJARAN PENDIDIKAN KEWARGANEGARAAN," J. Edueksos, vol. IX, no. 1, pp. 56-72, 2020.

[30] Supriyati, "Gerak Relawan COVID-19: Tanggung Jawab Sosial Individu dan Masyarakat," in Tata Kelola Penanganan Covid19: Kajian Awal, Yogyakarta: Gadjah Mada
University Press, 2020.

[31] E. Prasojo, "People and Society Empowerment: Perspektif Membangun Partisipasi Publik," 2003.

[32] S. Dharma, "Membangun Kesadaran Global Warga Negara: Studi Kebijakan Publik Di Era Pandemi Covid 19," Perspektif, vol. 10, no. 1, pp. 248-254, 2021.

[33] W. O. Z. Z. Toresano, "Integrasi Sains dan Agama: Meruntuhkan Arogansi di Masa Pandemi Covid-19," Maarif, vol. 15, no. 1, pp. 231-245, 2020.

[34] D. G. Nicolas, "Analisis Anggapan Rekayasa di Balik Pandemi Covid-19, Vaksin Covid-19 Berkaitan dengan Microchip 666 dan Antikristus," J. Revolusi Indones., vol. 1, no. 3, 2021.

[35] S. Hadi, "Pengurangan Risiko Pandemi Covid-19 Secara Partisipatif: Suatu Tinjauan Ketahanan Nasional terhadap Bencana," J. Perenc. Pembang. Indones. J. Dev. Plan., vol. 4, no. 2, pp. 177-190, 2020.

[36] Y. N. Harari, Sapiens: A Brief History of Humankind. Kanada: Signal Books, McClelland \& Stewart, 2014.

[37] H. Heriyanto, Paradigma Holistk: Dialog Filsafat, Sains, dan Kehidupan. Jakarta: Teraju, 2003. 